\title{
THE AESTHETICS OF ORGANISATIONS AS PHILOSOPHICAL AESTHETICS ${ }^{1}$
}

\author{
Ignasi Roviró ${ }^{2}$
}

In memory of Bartomeu Forteza

Peter Senge, the author of the famous book The Fifth Discipline $e^{3}$, and one of the leading experts in the world on organisational learning and development, believes that the world, wherever we look, is undergoing a change as important as that of the Industrial Revolution. Invited to address the annual meeting of the consultants HayGroup in Amsterdam last year, he said "while it is true that today there are machines with the capacity to learn, such as computers, they are not capable of reproducing themselves as living beings are. From this it

1 I would like to thank Jon Telford for agreeing to translate the article from the Catalan original. The work was done within the KAL Research Team of Barcelona University. The lecturers Bartomeu Forteza, Francesc Fortuny and Andreu Grau (all members of $\mathrm{KAL}$ ) have been the source of much encouragement and of many of the ideas explored here. Equally, Miguel Candel (Director of KAL) has made available to me the research published today.

2 Faculty of Philosophy, Ramon Llull University (Barcelona).

3 P. SENGE, The Fifth Discipline: the Art and Practice of the Learning Organization, New York, Century Business, 1993. 
follows that in the new era we must contemplate the company as a living being, rather than as a machine"1.

As we shall later insist, we start, then, with the conviction that organisations have a life of their own, a life that is subsidiary to the life of the people who form them. Starting from this premise, we understand that a consideration of the aesthetics of organisations involves focusing our attention on concepts that deal with the life, sensitivity and beauty of the organisation. An awareness of the history of Aesthetics as a philosophical discipline, and of its development over the years, allows us to do this. We are conscious of the fact that Aesthetics has undergone a fundamental change, leaving behind the idea that beauty is the founding element of the discipline and focusing instead on the concept of the unity of vital knowledge, and on reflections related to the production of art.

By organisation, we understand any organism that brings together and combines the efforts of different individuals in order to obtain a common goal, whether it be material, product or profits, or psychological or spiritual. In reality, what makes up an organisation is the will to do so, and agreement on its proposed ends. However, every organisation needs some material forms to constitute itself and to enable it to recognise itself as a living and intelligent organism ${ }^{2}$. And in so far as these forms manifest that which the organisation is, or wants to be, Aesthetics has a great interest in analysing and giving shape to these forms. Let me repeat that Aesthetics affirms the significance of every form and, at the same time, believes that every vital meaning requires forms in order to be expressed. Aesthetics, then, has to work with the significant form of organisations, either analysing the coherence and vitality of existing forms, or recommending the most appropriate ones for adoption.

Aesthetics aims to fulfil Schiller's maxim: "behave aesthetically", in the sense that the significant charge of all forms used is inevitable. This insight, that all forms are meaningful, has evidently produced what Vattimo and Baudrillard term, rather critically, a social

1 A summary of his speech can be found in J. PALAREA, "Crear valor a través de les persones", Revista de Qualitat, $\mathrm{n}^{\circ} 39$, October 2000.

2 Francesc Fortuny (KAL, Barcelona University) reminds me that these forms should not be understood as an aggregate that is added to a pre-existing content; rather, it is in the constituting of itself in the here and now of all intelligent life that forms and content are generated, in a discourse where the organisation's life in the here and now is recognised in intelligence. 
aesthetisation ${ }^{1}$. However, to counter this critical vision, a little despairing in its reference to what we have supposedly lost, we would affirm that aesthetisation, the attention to every social form, is in itself positive ; it makes for a more pleasant world, and not one that is simply based on fantasy, as these writers would have it. Aesthetics pays as much attention to the phenomenon of social aesthetisation as to that of elitist art.

In this article, then, we are fundamentally interested in the forms that express the life of organisations, understanding, however, that the whole organisation is present in every one of its forms. This question is approached from the perspective of Aesthetics in order to obtain an overall reflective vision. While it has been characteristic of philosophy since its earliest days to question, and to make us question, we need only remember the power of the "Apologia of Socrates", one of philosophy's founding texts, Aesthetics, in so far as it is philosophical, has to reflect on forms and their capacity for evoking sensations and, on the other hand, has to make us question and feel the manifest forms of organisations. To the extent that its vision is global, Aesthetics will demand transparency in this double process. Further, in its observation of the sensed forms of organisations, Aesthetics should provide clear indications as to : (1) what 'personality' is manifested through the forms observed, (2) what the action visualised is and (3) with what end in mind this action is performed. It will not judge the 'goodness' or the 'truth' of organisations, but rather the transparency that allows their visualisation.

Conditioned by the living context of forms, and by sensitivities in constant evolution, organisations have to define and redefine themselves perpetually in the three areas indicated, while knowing that they cannot escape from defining and identifying themselves using forms by which they will be 'understood'. It is from this perspective that we lay our claim to working jointly with the marketing expert, with the product designer and with the aesthetic creator of the transparent, visible and palpable manifestations of the product, or the organisational identity.

1 G. Vattimo speaks of this in La fine della modernità (1985), as does J. Baudrillard when interviewed by R. Scheps in Les sciences de la prévision (Paris, Éd. du Seuil, 1996). 


\section{Aesthetics : a perspective that implies the unity of knowledge}

The origins of Aesthetics as a philosophical discipline in pursuit of the complete unity of knowledge have been lost sight of. It was the German Enlightenment that illuminated the unity of this process : the laws that governed the senses were sought, in an attempt to unify them with the laws that governed reason. No dark corners were to be left in the explanation of human knowledge. In the earliest treatises on modern Aesthetics, which appeared from the mid-1700s onwards, the idea of beauty as the central element in Aesthetic reflection was abandoned and instead stress was placed on the idea of the senses being the primary elements that receive information from the exterior. In this way, the world of philosophy was brought even closer to that of sensed knowledge. Not that reason was counterposed to the senses ; rather it was stressed that a real understanding of the world could not be attained without both forms of knowledge : sense and reason. The German thinkers, from Baumgarten to the genius Hegel, taking in Kant with all his clarity, sought to demonstrate that Aesthetics is an understanding based on the knowledge of materiality, and one that starts with the consideration of the significant form of things.

Today, we retain from these masters the concept of the significant form. That is, the conviction that every form contains a meaning and that in the realm of organisations every meaning requires a form. Perhaps for this very reason, those in charge of American industry understood as early as the beginning of the 20th century that a product has to be 'designed', that care must be taken with form. This was the principle that inspired the work of the industrial designers. However, marketing seems to have lost sight of this extremely important fact, one of the essential elements of Aesthetics. Al Ries and Jack Trout ${ }^{1}$, the best known sales strategists in the world, Philip Kotler (author of Marketing Management ${ }^{2}$, the most widely used book on the subject in Marketing schools) and now Sergio

1 With titles as important as The 22 Immutable Laws of Marketing, Marketing Warfare and Positioning.

2 The tenth edition was published in 2000. No less successful is his Marketing. An Introduction (with Gary Armstrong, US Imports \& PHIPEs) : its fifth edition was published in 1999. 
Zyman ${ }^{1}$, in their numerous works on marketing seem not to remember that Aesthetics implies the integrity of knowledge, starting with sensed forms. To perceive is to know and to know is to perceive, the philosophers have told us throughout history, an insight that Aesthetics has sought to apply. For this very reason, from the standpoint of this discipline the term 'organisation' can be seen to be in itself aesthetic and is redolent of the concepts of 'suitable proportion', of the harmonia, claritas, esplendor formae... of the classics. 'Transparency', 'identity' and 'life' are three of the key terms that enable an understanding of the images that organisations offer.

\section{Transparency : when the organisation is translucent}

In an article published in Vol. 11 of the prestigious Design Management Journal ${ }^{2}$, Tom Peters draws on a book by Wally Olins ${ }^{3}$ to defend the notion of the total presence of an organisation in its actions. Olins underlines the idea that creating an identity in an organisation necessarily involves the creating of mechanisms designed to make that identity visible. This means, Peters points out, that working on identity means working on coherence. While we completely agree with Peters, it seems to us even more important to recall that, in the realm of aesthetics, the concept of coherence has a particular name. 'Coherence' is a term used in formal logic, and evokes the whole terminological artillery applied to propositions. Thus, the use of the concept of coherence calls to mind not only the other logic terms involved, but also the links between them. We well understand Peters' intentions. However, we prefer to use the vocabulary, and hence the content, of Aesthetics and speak of 'transparency' as the manifestation of the particular life of an organisation. In this way we refer not to logical-formal connections between the various components (something which the term 'coherence' aspires to and values), but rather to demonstrating the

1 El final del márketing que conocemos, Granica, 1999.

2 T. PETERs, "Design as Advantage No.1 Design + Identity", Design Management Journal, vol. 11, $\mathrm{n}^{\circ} 1$, Winter 2000.

3 Corporate Identity, Boston, Harvard Business School Press, 1990. 
interrelationships that the various living parts of an organisation establish between themselves to better adapt to their environment, to enhance their lives and the various sensed forms they adopt, and at the same time, to increase the full and active assimilation of these forms in the life of the subject receptor.

By definition, transparency allows the seeing of what is; the word comes from the Latin transpicio (trans, specio), to see through, and it is the opposite of opacity (opacus, that which casts shadows). Applying this concept to the reflecting of organisations involves : (1) demanding the complete visualisation of the whole life of the business, (2) questioning the mechanisms used in this visualisation and (3) making it clear that for an organisation to be fully transparent, concordance between (1) and (2) is fundamental. Thus, the completely transparent business is one which treats itself as the end product of its activity. A business is transparent if its activity is aimed not at the selling of a product but rather the manifesting of itself. The product is then an intermediate step on the journey that includes both the organisation and the product manufactured, or the service given, the intermediary and the 'final consumer'. In the transparent company, the objective is the demonstration of its own life, the presentation of itself, warts and all, to the public and to itself ${ }^{1}$. Therefore, and from the standpoint of Aesthetics, rather than a 'coherent' organisation, we are interested in the 'transparent' life of the organisation. Let us look at two particular cases : one where transparency generates trust, and one where the architectural materiality is transparent.

\section{Transparency as trust : the case of Prodhag Plastiques}

Prodhag is a clear example of how opting for transparency is more than a mere publicity slogan. In this company it is not a question of selling a product, and it goes further than the offering of a service in exchange for money. The key element is that of basing the

1 "Les ha dado el nombre de "organizaciones caórdicas", una contracción de caos y orden. Son organizaciones que parecen generar orden del caos como oposición a las organizaciones tradicionales que intentaban imponer el orden ( $\mathrm{y}$ a menudo acababan produciendo mucho caos)". P. SENGE, A través del ojo de la aguja, in R. GiBSON, Preparando de futuro, Gestion 2000, 1997, p. 161. 
client-supplier relationship on transparent human relations : on trust and honesty. This attempt might well have remained merely superficial were it not for the efforts made to ensure that these fundamental relationships of trust and honesty were the very basis on which the company was built. That is to say, both the external appearance and the interior life of the company were constructed on these precepts. Opting for transparency means making the people who form the organisation the key element, and this implies changes in philosophy, aesthetics, procedures and management systems that affect the traditional structure of a company. It should be pointed out that in any organisation wholeheartedly applying these ideas, the installations, graphic symbols, logo and other aesthetic and design details should all exude transparency, a radical idiosyncracy ${ }^{1}$.

Prodhag is a French company, based in the Rhône-Alps region, which processes plastic materials for recycling. The company was set up in response to the need for such a service, and to the requests of some ten businessmen who were personally acquainted with Alain Vallette d'Osia, the current Managing Director of Prodhag Plastiques". He explains, "My interlocutors, clients and suppliers, and I established links based on honesty, transparency and technical competence"3. In order to guarantee his clients ongoing transparency and honesty in their business relations, M. Vallette selected

1 "Prodhag est née de l'externalisation et externalise elle-même." P. Bourgeors, "Prodhag. Le prestaire qui externalise", Cahiers industries, n 48, p. 20.

2 "L'unique activité de cette entreprise familiale de Colombe en Isère est centrée sur la transformation de matières plastiques par broyage. L'entreprise enlève chez les plasturgistes tous les déchets neufs de production thermoplastique sous différentes formes (pièces rebutées, carottes, chutes et détourages...) et les broie à la convenance de ses clients. "Une dizaine d'entreprises de plasturgie sont à l'origine de Prodhag, explique Alain Vallette d'Osia, son directeur. Le poste de broyage constituait pour chacune d'elle un mal nécessaire et une source de désagréments : bruit, poussières, manque d'intérêt pour un travail non valorisant, stockage des rebuts... Nous nous sommes placés sur ce créneau pour leur permettre de résoudre tous ces problèmes en leur garantissant la transparence ". L'externalisation de cette fonction a permis aux plasturgistes de se centrer sur leur cœur de métier, de conserver un plus haut niveau de qualification de leur main d'oeuvre et d'accroître leur chiffre d'affaires. Quant à Prodhag, elle réalise pour le compte de ses clients la gestion complète de leurs déchets, à un prix souvent inférieur au coût de revient estimé. L'entreprise a ainsi traité l'an passé quelque $150000 \mathrm{~m} 3$ de matières premières, soit l'équivalent en volume de 2400 semi-remorques. Elle importe ses matières premières de toute la France et exporte ses produits principalement en Europe (65\% du tonnage), Ibid.

3 Alain ValletTe D'OSIA, "Prodhag : un exemple del compromís del dirigent amb la qualitat i la motivació del personal", Revista de Qualitat, n³8, July 2000, p. 15. 
professional managers with convictions and ethical postures that fitted the kind of business he wished to create. However, that was not sufficient. Apart from the managers, it was also necessary to identify procedures and a recognised management system that would guarantee, within the framework of a 'transparent' company, the possibility of making the company work'. The director of Prodhag Plastiques says: "We have gained the trust of our clients because we have respected the commitments we made, because we have, I believe, been honest, and because we have also been transparent. We maintain this trust thanks to a perfect equilibrium between the human, industrial and financial aspects"2.

Nevertheless, it is not possible to base a business on trust and leave this concept in the vague realm of external relations or to consider it simply as asset management. To gamble on trust as the company's defining element, and allow the transparency of all the company's actions to manifest this trust, means affirming that this value extends into every corner of the organisation. The question of the equitable and just division of the wealth created was necessarily one of the keys to success. This clearly suggests that a belief in the human factor is the principal value of the organisation. Working in this way involves a revolution, changing from the vision of the company as a producer of goods, with a highly developed pyramidal

1 "Par ailleurs, l'entreprise a mis en place un système de management environnemental certifié ISO 14001 qui offre une garantie pour le recyclage et la valorisation des matières premières qui lui sont confiées. Ce système fait partie du programme Adege (Action de développement de la gestion environnementale) (...). La démarche est rentable à plusieurs points de vue : financier (économie de charges), commercial (gain de parts de marché, adaptation aux marchés internationaux), marketing (amélioration de l'image de marque), technique (amélioration des procédés, utilisation de technologies plus adaptées) et juridique (respect des textes réglementaires et anticipation de leur entrée en vigueur par une veille). Cette démarche lie Prodhag, ses fournisseurs et ses clients dans un partenariat très poussé. Mais l'entreprise n'en reste pas là. Elle externalise à son tour une partie de ses fonctions d'entretien, de gardiennage, de transport, de logistique ainsi que ses services juridiques. Pour certaines d'entre elles, les contrats qui lient l'entreprise à ses prestataires sont très rigoureux. Le transporteur qui bénéficie de l'exclusivité du marché doit ainsi mettre ses camions aux couleurs de Prodhag. Toutefois l'entreprise conserve la production, la recherchedéveloppement, la comptabilité et le marketing. "Les PME sont les chevaux légers de l'industrie, remarque Alain Vallette d'Osia. Leur résistance est faible contre les coups de boutoir de la concurrence internationale et de l'évolution des marchés financiers. Si elle est bien conduite, l'externalisation est un moyen efficace de les rendre plus réactives et de pérenniser leur existence". P. BourGEOIs, op. cit, p. 20.

2 Alain VALLETTE D'OSIA, op. cit. p. 16. 
structure, to that of an organisation that manages human relations, where the directors have their powers limited by the decentralisation of responsibilities". Alain Vallette d'Osia puts it like this: "The human being is the principal asset of the company. Consequently, when this fact is respected through an equitable division of the wealth produced, when the work done is valued, and when even the most basic tasks are recognised, the situation of trust is rapidly recovered (...) We managed to motivate our personnel with the following "weapons": a wages policy based on one fixed amount and two variable quantities : individual bonuses (that reflect the effort made by the individual) and collective bonuses (based on the company's results and a contracted and significant profit-sharing agreement, a savings plan and a quality bonus)"2.

\section{Material transparency : the case of Prosa}

University of Michigan MBA lecturer, Dave Ulrich, believes that it is necessary to encourage the development of a more flexible and transparent model of company. A company 'without frontiers' between departments, where there is a constant flux of knowledge between the sections and divisions ${ }^{3}$. We would argue that it is necessary to go a little further. Stretching Ulrich's idea, we are interested to see what happens when transparency extends to the very material dimension of the company, when the walls themselves are organisation. This is the case with the newspaper $\mathrm{El} 9 \mathrm{Nou}$, a

1 "Limiting the powers of the businessman. One thing is true : the businessman does not need to have all of the powers. If he trusts those who hold them and if they put those powers at the service of everybody, if he delegates and oversees, the businessman maintains his role as the locomotive that hauls the train to which carriages are progressively added. From time to time, the inertia of the train allows a certain relaxation and a stepping back to gain an overall vision of the distance travelled." Ibid. p. 18. In a similar way, Michael Hammer -in Mas allá del fin de la gestión empresarial-insists: "Necesitamos un modelo en el que las personas en primera línea, armadas con una estrategia básica decidida por los altos directivos de la empresa, tengan mucha autonomía y responsabilidad para decidir por ellos mismos. Un modelo donde la gestión exista, no para dirigir y controlar o supervisar, sino para facilitar y capacitar" (Cf. R. GIBSON, op. cit., p. 123).

2 Alain VALLETTE D'OSIA, op. cit., p. 17.

3 He made it explicit at the annual meeting of HayGroup Consultancy, held on this occasion in Amsterdam, and attended by representatives from more than seven hundred companies from around the world. The title for the 2000 meeting was Crear valor a través de les persones. 
publication aimed at local readers in the towns and villages of central Catalunya (grouped, according to the Catalan denomination, into comarques). The publisher, Prosa, has a turnover of some 4,808,097 euros per year and puts out three editions : one for the comarques of Osona and el Ripollès, one aimed at the comarca of el Vallès Oriental and another in el Vallès Occidental. Unlike the national press, El 9 Nou publishes local information and works with issues that directly affect the local population. It is this proximity to the reader and the news that also imposes an informative transparency that, since its foundation in 1978, the newspaper has always worked towards. The general ideological criteria of the paper are: independence, an institutional sense, sense of national identity, social interest, progress and innovation, professionalism and a sense of comarcal identity. It is aimed at a population of more than 1,000,000 (one sixth of the total population of Catalunya) and has a circulation of 35,000 copies (23,000 in Osona and el Ripollès split between the Monday and Friday editions ; and 12,000 in el Vallès Oriental, also split between two editions) and sells on average 2,888 copies in el Vallès Occidental. In total there are some 5,400 subscribers.

The Managing Director of El $9 \mathrm{Nou}$, Jordi Molet, defines the organisational structure as a "flat hierarchy". This concept refers, fundamentally, to the division of powers and responsibilities between the various sections. Thus, for example, the decision about what news is published, the space dedicated to each story and the importance attached to each piece, is a joint decision taken by the Editorial Council, which comprises the Director, the Head of the Newsroom, and the Reporters. The newspaper's Board of Directors does not intervene in any way in any of the editorial decisions made by the three Editorial Councils (Osona and el Ripollès, el Vallès Oriental, and el Vallès Occidental).

The fact that transparency is a pre-requisite in journalistic work is reflected in the building that houses the headquarters of this newspaper, a mansion in the old heart of the beautiful medieval city of Vic, a strategic communications and business centre between Barcelona and the French border. The aim was to make the internal and external walls, the divisions and the structure, transparent. Thus, the architects, Pallarols and Padrós, incorporated transparency, the defining characteristic of the company, into the stone shell of the building. They looked for ways to include architectural elements in the unified whole that is the organisation. They created a single 
transparent space for a singularly transparent organisation. The solution they came up with involves the thoughtful use of glass, and a homogenous distribution of space avoiding unnecessary divisions. In this way, the newsroom is essentially one large room that occupies a whole floor. The reporters are located in a single shared work space. From the street outside, the glass allows the observer to glimpse, and hence enter, the world inside, to form part of the work and to become, even if only momentarily, one more element in the organisation.

This newspaper has managed to inscribe transparency into a stone space, but has also worked on the concept in a wide variety of aspects of its organisational life. The most important of these are : the Style Book (1991), the Graphic Design Style Book (1994), the work done to create an Ethical Code, and the attention paid to the rulings of the Consell de la Informació de Catalunya (a body that works to promote transparency and journalistic quality in the Catalan press).

\section{"Identity" versus "representation"}

To take the question of the identity of a collective to its logical conclusion means questioning identification, the ways in which each member of the group lives, and expresses in sensed forms, the identity of the organisation'. As has already been implied, we would argue that the life of every organisation is rooted in, and depends on, every single individual who forms part of the organisation. Hence, when Aesthetics affirms that identity is one of its key terms, on one hand it is underlining that it is through sensed forms that identity is manifested and perceived, while on the other, it is demanding that these sensed forms be truly living, and that they identify each and every member of the whole. For this reason, we reject an organisation based on representation (whether this be through the use of graphic symbols, rhetorical-linguistics or of any other kind). Our aim is not representation as such, but rather the life of the organisation as a whole. This should not be taken to mean that representational resources will not be used when necessary, but rather that we cannot accept the concept of an organisation where each of the individuals, or

1 One aspect that we can not deal with here is the interesting idea of an anthropological-semiotic analysis of the identity of our culture, or some of its aspects. Jean-Marie Floch has done this is his work Identités visuelles, Paris, PUF,
1995. 
sections, that make up the whole, is re-presentational. That is to say, that their presence, their position, is determined by another presence (and a superior one at that, hierarchically speaking).

A philosophical-aesthetic revolution is needed within organisations to strengthen the creative and experiential role of each of their members ${ }^{1}$. Every subject should experience their own particular identity within the organisation, should cultivate the most positive contributions that their personality allows them to make, and at the same time should perceive that it is through this profound experiencing of their own identity that they can identify themselves as members of the organisation. This dual process, the strengthening of the identity of each and every one of the subjects, and of their identification with the organisation, corresponds perfectly with the goal pursued here: that the organisation becomes subject (it is humanised) and in their turn the subjects become organisation. In this way, the universality of the organisation is not obtained by denying the particularity of its members (this would be the basis of the representational model of an organisation), but rather the globality of the organisation is achieved through the reaffirming and reinforcing of each of the diverse identities that make it up. For Aesthetics, the greater the amount of representation introduced into an organisation, the higher the level of opacity. Against this hierarchicalrepresentational model of an organisation, we would argue for the centrifugal-centripetal force of identity. The more identity, the greater the manifestation of life, and of the life of the organisation.

This philosophical-aesthetic revolution necessarily involves careful work on the sensed forms, both of the individuals and the organisation itself ${ }^{2}$. Further, when careful attention is called for with

1 Francesc Fortuny notes : And for this "revolution" it is necessary to pension off Modernity and not create oppositions between things and products, or psychologies and clients ; rather urging people in the direction of personal integrative activity. If the activity of the company is aimed at promoting integrative action and not consumerist passivity or the docility of infallible formulas, then Modernity and consumption will truly be finished with ; consuming more and better, the quality of life will increase in line with the quantity of production. It is a question for intelligent entrepreneurs of a combination of market ethics and aesthetics.

2 A parallel aspect is that of work on emotional bonds. Josep Ma. Fons Boronat, Professor of Business Organisation at the Universitat Politecnica de Catalunya, underlines this: "We understand the purpose of the organisation to be that of providing the personnel with a sense of identification with the organisation, a feeling of pride in being a member, and a sense of commitment with regard to the future. However, to achieve this it is not enough to rely simply on the persuasive 
the sensed forms, this does not only refer to the most obvious ones -the more material forms. This work is also necessary in terms of the rhetorical-symbolic forms, what has been called the 'culture of the organisation'1.

Here we must make reference to the very valuable book by Bernd Schmitt and Alex Simonson ${ }^{2}$ for whom working sensed forms is working on identities and the processes of identification. They are very clear when they state, "Managing an identity means carrying out

logic of strategic analysis; instead, it is necessary for the personnel to have an emotional bond with the organisation (...) For this to happen, the work of the subordinate has to be given 'meaning', their contributions must be recognised, and commitments must be made to their personal development and to increasing their capacity for initiative" ("Gestió del canvi", Revista de qualitat, $\mathrm{n}^{\circ} 36$, January 2000 , p. 19.

1 The Managing Director of the Commuter Trains Division of RENFE, the Spanish railway company, Sr. Abelardo Carrillo, reflects on questions related to this theme : "A fundamental aspect in the survival of identity is the existence of 'internal' symbols and language. It may on occasions seem trivial to us that groups or individuals require symbols that explicitly characterise their cultural identity. Businesses need them to compete, but also to maintain the distinctiveness of those internal messages that feed the sense of belonging of the individuals that make up the company. The reaffirmation and reinforcement of these languages is quite simply essential in the maintaining of the internal energy of the organisation. For the same reason, preserving them from the contamination that would result from misuse, dissipation or elimination, is a task in which the heads of the company must show themselves to be intransigent. Caring for/about language and its symbolism constitutes a fundamental principle in the preservation of the cultural identity of a business; the radical defence of this principle will also serve to indicate the identity of the organisation" ("Tot tornant al factor humà", Revista de Qualitat. Centre de qualitat. Generalitat de Catalunya, ${ }^{\circ} 40$, January 2001, p. 6). Carrillo refers to a theme of great breadth and about which much has been written -that of culture. For Charles Handy, in Gods of Management, (Pan Books, London, 1978) it was a central concern. Twenty years later Stephen Covey was to detect the generalisation of the idea : "Todas las organizaciones empiezan a hablar de esta manera (...). Siempre que voy a sus reuniones oigo lo mismo porque se están dando cuenta de que en el movimiento de calidad del pasado el énfasis estaba en las tecnologías y en las estructuras, sistemas y procesos y no en la construcción de culturas de alta conflanza" (Los principios primero, p. 54). A brief and effective approximation to the concept was presented by Franc Ponti : "La cultura empresarial es, utilizando un símil, una especie de gnoma organizativo que contiene la información sobre la manera de ser de una empresa. Culturalmente, una empresa puede ser abierta, cerrada, adaptable, inflexible, paternalista, innovadora, intolerante, anticuada, moderna y un sinfín de cosas más" (La empresa creativa, Granica, 2001, p. 134).

2 B. SCHMITT, A. SimONSON, Marketing Aesthetics : the strategic management of brands, identity, and image, New York, The Free Press, 1997, translated into Spanish in 1998 for the publishers Deusto under the title Márketing y estética. La gestión estratégica de la marca, la identidad y la imagen. 
a detailed study of the strategic vision in order to create sensorial stimuli and forms of communication that evoke that vision, that represent the identity" (58) or, "The heart of the question of managing identity lies in the creation of a company (or brand) aesthetic that expresses the 'character' of the company (or brand) using attractive identifying elements" (68).

Schmitt and Simonson, renowned American marketing professionals, base their professional activity on the creation of consumable sensed experiences that express the identities of their corporate clients. They work in two ways : from the point of view of the company, they create a 'personality' for the organisation, identifiable through sensed forms, designed precisely to express that 'personality' ; from the standpoint of the consumer-receiver, they

1 The process of creation-evolution of the personality of an organisation is not in any sense simple. Like the living organism that it is, a corporation evolves in line with (1) external, contextual influences, (2) its own life cycle and (3) the life cycles of the subject creators who comprise it. There are a whole series of mechanisms available for use in the creation of the personality of the corporation and in the identification of individuals with it. An initial example can be found in the improvement process undertaken in the textile company Tejidos Estambril, SA, makers of protective fabrics: "The setting up of work groups (named 'bubbles' in Tejidos Estambril, SA) has also allowed many people to participate in the suggestion of improvements that this structure encourages. Through these 'bubbles', the full identification and involvement of the company personnel has been achieved, enabling the staff to take initiatives, and creating the consensus for implementing changes to deal with the problems studied" (ANON, "Tejidos Estambril SA", Revista de Qualitat, $\mathrm{n}^{\circ}$ 40, January 2001, p. 23. A second example is presented by Sr. Pedro de Esteban, Chairman of the company Ibex : "The direct participation of the whole staff, in both the identification of the processes to study and in the making of proposals for improvements, has led to a high level of integration not only in terms of their awareness of key competitive factors, but also in the introduction of improvements and in the sense of 'company'. This participaction combined with total transparency in the frequent issuing of company results (sales, budgets, quarterly results, etc), has led the staff to live the company in their daily life and feel identified with its evolution". ("Ibex : l'equip humà com a motor del canvi", Revista de Qualitat, $\mathrm{n}^{\circ} 38$, July 2000 , p. 14). The identification of individuals with the organisation is, according to Aries de Geus, one of the factors that enable businesses to have a long corporate life span (cf. A. DE GEUS, La empresa viviente, Granica, 1998, pp. 23-24, 28 and 284 ; he had already referred to this idea in "Living Company", Harvard Business Review, March-April 1997). Finally, we have the opinion of Patrick Fricke, renowned manager of Graphic and Visual Interface Design, Design Resource Center, Eastman Kodak Company, who points out that design influences the process of identification: "Excellent design practices influence corporate identity, affect day-to-day operations, and are consistent with the strategic goals of an organization" (" 18 views on the definition of Design Management", Design Management Journal, Summer, 1998, p. 15). 
analyse the sensations experienced in the visualisation or utilisation of the forms designed.

Considered in this way, the result aspired to by Schmitt and Simonson is an agreeable symbiosis, where the exchange 'money for product' is nothing more than a brief moment, and not the most important one, in the relationship between the producer and the client. The market is now seen as the purveyor of new experiences, guaranteeing complete satisfaction -this is why sensed forms and the experiencing of sensations have become so crucial.

\section{The life of the organisation : its images}

The York University lecturer, Gareth Morgan, published, in 1986, Images of Organization ${ }^{1}$ a book recognised as unique, and of great use in the developing of an understanding of the conceptual paradigms that govern the thinking of organisations. In terms of the application of Aesthetics to the study of corporations, Morgan's text is of interest since it uses metaphors to describe the structures of organisations. That is to say, we find ourselves in the realm of the analysis of rhetorical devices, and specifically that of metaphors -those sharp tools that make a magical connection between an image and an idea. If the metaphor fits perfectly, its force is incalculable. However, where there is an imbalance in favour of the image, the idea disappears. For us, this is the danger of Morgan's book ; the brilliance of the form and the suggestiveness of the imagery leaves us mired in metaphor.

Morgan analyses eight metaphors that aim to explain the life of organisations : (1) the machine: a combination of pieces that fit together, each of which has a very specific role in the overall efficient working; (2) the biologist : the conception is of the organisation as a living being, ecologically speaking, that relates to its environment, that is born, grows, reproduces itself and declines ; (3) closely connected with the former, the organisation as a brain, that directs and thinks, and that deals with information. This also focuses on the concept of efficiency ; (4) the metaphor of the culture tries to explain the symbolic meanings, the systems of shared meanings, the nature

1 We have used the French translation: Images de l'organisation, Québec, Presses de l'Université Laval, 1989. 
and significance of the organisation in terms of its surroundings. This is a useful tool for understanding the internal changes within an organisation; (5) here the organisation is seen as a political system, as a combination of interests and conflicts, of power games that determine the activities of an organisation. This metaphor helps us to understand how the life of an organisation is based on conflict ; (6) the metaphor of the organisation as a psychic prison, for which Morgan goes back to the myth of Plato's cave. He explores the idea of the organisation as a combination of conscious and unconscious psychic processes, where the image, the ideas, the thoughts and actions that arise out of these processes, 'imprison' those who are subjected to them; (7) based on the ideas of David Bohm, the organisation is seen as flux and transformation; (8) le côté répugnant: organisations are seen as instruments of domination. Here, he insists on the potentially exploitative character of organisations (in fact, an extension of the metaphor of political game playing).

The limitation of Morgan's book, faultless in its formulation, is that it does not go beyond the rhetorical device. When, from an Aesthetics standpoint, we affirm that the organisation is a living being, we have already made the leap from metaphor to description, while Morgan's biologist metaphor, for example, is no more than that -a rhetorical device based on a model of biology. Set against the limits of this metaphor, ours is a semiotic posture that aims to explain that the life of an organisation comes from 'within' itself. The actions of organisations are the actions of the people who carry them out. It is only in this way that I can understand organisations, any organisation ; as a group of people who, together, undertake particular actions with a view to some particular end. Morgan, effectively, makes metaphors, we do not. He uses an image in order to think while we reflect on the images organisations give us and we remind them that every image conveys a meaning. Thus, we affirm that today it is for their images that organisations are known. Or to put it more bluntly, an organisation is simply the combination of images it displays. We should bear in mind that the methods aimed at continually improving quality are not only concerned with the product but also with its form. Our companies have finally understood that the form of the product and its quality are not separate : form is one of the 
qualities, and a product's qualities, capacities and performance are its form.

The position of Aries De Geus ${ }^{1}$ is at the other extreme ; for him, an organisation is a person. He takes as his starting point the characteristics that the German philospher Stern attributes to persons, and making a metaphysical jump that is difficult to explain, applies them to institutions ${ }^{2}$. He then populates the universe with a hyperorganicism that ranges from single cells to a multinational, yet attributes indiscriminately to all these elements the same human consciousness and motivations. The error, it seems to me, lies in presuming that all the prerrogatives of individuals also apply to organisations ${ }^{3}$. This leap, which is philosophical-ideological, not semantic, is not even accepted by the laws that regulate corporate activities. We may talk of companies as being living entities in the sense that the individuals who determine their actions are living beings, but it is far from justified to convert organisations into individuals. The term 'person' is very old ; the history of the usage of the concept in the classical tradition records 18,882 appearances in the Patrologia latina, and 15,159 in the Corpus christianorum. Our intention here is only to argue the need for care in the use of this concept because, like images, words are redolent of their history. And while it is the context that determines the meaning of words, words themselves are never 'innocent' ; they have their own history. De Geus' difficulty arises from the fact that he has forgotten the history of the term and its usages.

1 Living company, Harvard Business Review, and extended into a book The Living Company. De Geus has worked for Royal Dutch Shell, is a lecturer at the London Business School and a member of MIT.

2 For De Geus, every organisation "is goal-oriented" (136), "the behaviour of a corporation (or its divisions) can not be explained solely through causes and effects" (136), "every division of the company is self-aware" (137), "All those associated with any of these divisions are conscious of its limits, of who is included and who excluded" (137), "every division finds itself open to the outside world." (137) and "every division of a company, being alive, has a finite life-span" (138). A. DE Geus, La empresa viviente, Granica, 1998.

3 "What I have come to call living companies have a personality that allows them to evolve harmoniously. They know who they are, understand how they fit into the world, value new ideas and new people, and husband their money in a way that allows them to govern their future. Those personality traits manifest themselves in behaviors designed to renew the company over many generations. Throughout, living companies produce goods and services to earn their keep in the same way that most of us have jobs in order to live our lives" (A. DE GEus, "Living company", Harvard Business Review, March-April 1997, p. 52). 
Almost ten years ago, Tom Peters stated that, in the forthcoming two decades, "design" would be the key factor that would distinguish the high-tech corporate winners from the losers ${ }^{1}$. However, we are convinced that when Peters spoke of "design", he was thinking of aesthetics ${ }^{2}$. At the very least, this is certainly true in the sense we have tried to explain here : that organisations that rethink themselves, that rethink their own sensed forms, that strengthen their sense of identification, and make their actions and ends more transparent, will approach the level of translucence peculiar to those sensed forms that, throughout history, have moved humanity.

1 He expressed this idea in Liberation Management, a book translated into Spanish under the title Reinventando la excelencia, (cf. p. 919 of the translation).

2 Having read him, everything would seem to point in this direction: "Design is in the eyes. The ears. The nose. On the lips. The fingertips. To 'get' design, you must become a tuned-in student of the senses...", especially if, in addition, all of this is admitted as knowledge. (T. Peters, "Design as Advantage No.1. Design + Identity", op. cit.). On the other hand, we can not forget the works of one of the freshest architects. While his position is extremely interesting, we feel that William A. McDonough, architect and ecological-environmental designer of all kinds of industrial products (from a factory to a fabric) does not go far enough. He argues that design is more than making the product aesthetically attractive ; rather it is a question of optimising its relationship with the environment (cf. the publication by the team of architects Nikken Sekkei, Sustainable Architecture in Japan: the green buildings of Nikken Sekkei, edited by A. Ray-Jones and with an introduction by E.Maki and W. A. McDonough. Published by Sussex, Wiley-Academy, 2000). McDonough, in other words, is saying that every form is significant and that special care should be taken with the form used. He argues for an eco-form. We cannot maintain the opposition between form and content : today, form has become the true content and all that is content is so for the form it uses. It is in this way that Aesthetics becomes an urgent form of knowledge. 